\title{
WEJŚCIE SMOKA
}

Rola „poznańskiej historii sztuki” w polskiej historii sztuki po roku 1970 wymaga szeroko zakrojonego i wielostronnego przebadania. Dla zapoczątkowania tych badań przedstawiam tylko jeden moment tej długiej już historii. Przyjmując ściśle prywatną perspektywę, wracam do sytuacji, w jakiej spotkałam się z „poznańską historią sztuki”, którą to sytuację nazwałam „wejściem smoka". Popkulturowo-marketingowy tytuł nie uchybia uczoności, natomiast dobrze oddaje impet, $z$ jakim grupa młodych historyków sztuki z Poznania przebiła się na zacną i zasiedziałą scenę polskiej historii sztuki.

W roku 1970 rozpoczęłam - przypadkiem i niespodziewanie - pracę w Instytucie Historii Sztuki UW. W następnym - 1971 - „fuksem”, jak to określił mój promotor, profesor Jan Białostocki - obroniłam doktorat. Byłam zatem w pozycji optymalnej - uniwersytecki etat, najmłodszy wtedy doktor w dyscyplinie, a przede wszystkim poczucie satysfakcji i bezpieczeństwa, że jako młody historyk sztuki znalazłam się w miejscu najlepszym z możliwych. Może nie w pełni, ale zdawałam sobie sprawę, że polska historia sztuki lat 60. (czyli lat moich studiów) była dziedziną tradycjonalną, o pozytywistycznych, dziewiętnastowiecznych korzeniach, skupioną na badaniach faktograficznych i inwentaryzacyjnych sztuki polskiej, bezrefleksyjnie adaptującą pojęcia, metody i klasyfikacje wypracowane przez „zachodnią” historię sztuki (to ostatnie dotyczyło także historii sztuki XX wieku, zwłaszcza historii awangard). Natomiast poczucie komfortu zapewniała obecność na Uniwersytecie Warszawskim Jana Białostockiego, który wtedy był już uczonym o międzynarodowej renomie. Wiele podróżujący, uczestnik międzynarodowych organizacji, znający wielkich uczonych tego świata, autentycznie zaprzyjaźniony z Erwinem Panofskym, a jednocześnie bezpośredni i skromny w kontaktach z polskimi kolegami, stwarzał iluzję, że ten wielki świat kongresów oraz prominentnych periodyków i wydawnictw jest czymś w zasięgu ręki. Chociaż pozycja profesora Białostockiego bezpośrednio nie przekładała się dla nas na jakiekolwiek przywileje czy ułatwienia, na przykład stypendialne (Białostocki nie budował wokół siebie „dworu”, „stajni” ani „sszkoły”), sama jego obecność w Instytucie 
skutecznie chroniła przed niszczącym poczuciem polonocentrycznej prowincjonalności.

Natomiast zarówno kończąc studia, jak i później, rozpoczynając pracę uniwersytecką, praktycznie nie znałam żadnego historyka sztuki z Krakowa czy Poznania, o mniejszych ośrodkach nie wspominając. Byli co najwyżej pozycjami bibliograficznymi, czasem obowiązkowymi. O niektórych krążyły anegdoty lub byli przez moment przedmiotem zainteresowania medialnego (jak np. profesor Zdzisław Kępiński z racji ryzykownej atrybucji Stwoszowi mało znanego ołtarza). Dotyczy to przede wszystkim ciała profesorskiego, które - widziane z dzisiejszej perspektywy - na okolicznościowych fotografiach wygląda jak grono „facetów w czerni”, personifikujących obowiązkowe lektury. Owa wsobność nie była wynikiem zamierzonego izolacjonizmu. Komunikacja międzymiastowa - także ta uniwersytecka i naukowa - była słaba. Tak po prostu było, z różnymi stereotypami i uprzedzeniami włącznie.

Profesor Białostocki - co jest jedną z jego zasług - jako wieloletni prezes Zarządu Głównego Stowarzyszenia Historyków Sztuki usiłował przełamać izolację (czasem niechętną) polskich ośrodków uniwersyteckich historii sztuki. Temu służyć miały publikacje materiałów ogólnopolskich sesji naukowych, które aczkolwiek odbywały się od lat 50., nie były zbiorczo ogłaszane drukiem, pozostawały rozproszone i tym samym pozbawione funkcji integrujących środowiska naukowe. Pierwszy tom - Późny gotyk. Studia nad sztuka przełomu średniowiecza i czasów nowych, zbierający wystąpienia na konferencji odbytej na wrocławskim ratuszu w roku 1962 - zadedykowany został pamięci ks. profesora Szczęsnego Dettloffa. Nawiasem mówiąc, owe nadal publikowane tomy, aczkolwiek tematyczne, ale zawsze o strukturze sylficznej, są kapitalnym materiałem do badania dziejów polskiej historii sztuki ostatnich 70 lat - jej naukowej, intelektualnej i duchowej kondycji.

Właśnie jedna z dorocznych sesji naukowych SHS - odbywająca się w roku 1974 w Muzeum Narodowym w Warszawie konferencja „Myśl o sztuce" - stworzyła sytuację, która jest przedmiotem mojej refleksji, a raczej próby rekonstrukcji ówczesnych emocji. Zdaję sobie sprawę z ryzyka podobnych retrospekcji, ale je podejmuję, gdyż raczej chodzi mi o aurę wydarzenia niż jej kronikarski zapis. Sesję, inaugurowaną przez nestora w osobie Władysława Tatarkiewicza, zamykało wystąpienie Jana Białostockiego podsumowujące 40-lecie działalności SHS. A w tych ramach wygłoszono ponad 20 referatów, m.in. Andrzej Rottermund mówił o architektonicznych teoriach Duranda, Jacek Woźniakowski o angielskich krytykach, Elżbieta Grabska o Goncourtach, Maria Rzepińska o teoriach polskiego koloryzmu. Programowo część wystąpień poświęcono polskim historykom sztuki: Atanazemu Raczyńskiemu, Władysławowi Łuszczkiewiczowi, Zygmuntowi Ba- 
towskiemu, Oskarowi Sosnowskiemu, Władysławowi Podlacha. Było zatem godnie, interesująco, było w czym wybierać, byli świetni autorzy, było merytorycznie, co nie zawsze na sesjach SHS się zdarza. A jednak nie to sprawiło, że w pierwszym impulsie gotowa byłam określić tę konferencję jako „wejście smoka".

Ewenementem, który to sprawił, była - w swojej mocnej formie i krytycznym tonie obca sesyjnym obyczajom - gwałtowna polemika młodych przedstawicieli poznańskiej historii sztuki z referatem Zofii Ostrowskiej-Kębłowskiej Problem historyzmu w badaniach nad architektura wieku XIX. Publikowany w tomie sesyjnym zapis tej dyskusji w żaden sposób nie oddaje jej rzeczywistego charakteru. Przede wszystkim nie oddaje pasji, $z$ jaką była toczona, i emocji, jakie wzbudziła na sali. Znamienne, że dyskusję wywołał nie tekst poprawny, lecz znakomity, szerokością horyzontów badawczych i metodologiczną samoświadomością przewyższający większość wystąpień. Z taktycznego punktu widzenia polemistów słusznie właśnie on stał się przedmiotem krytyki, gdyż swoją klasą nadawał dyskusji wysoką naukową rangę. Wielogłos, jaki usłyszało konferencyjne zgromadzenie, był publicznym, „ogólnopolskim” debiutem „polemicznej” i „krytycznej” historii sztuki, jaka $z$ anarchicznym impetem objawiła się na XII Kongresie Historii Sztuki w Kolonii w kwietniu 1970 roku. „Nigdy przedtem ani potem żadne obrady jakiegokolwiek gremium historyków sztuki nie zdobyły w Niemczech tak wielkiego i publicznego rozgłosu" ${ }^{1}$. Najkrócej mówiąc, historia sztuki jako dyscyplina akademicka została tam poddana totalnej krytyce, inspirowanej różnymi nurtami neomarksizmu, i poddana rewizji jako jeden $z$ istotnych składników ideologii klasy panującej/władzy, w Niemczech dodatkowo skażonym kolaboracją z reżimem nazistowskim. Celem rewizji stało się podważenie paradygmatów dyscypliny, przede wszystkim zakwestionowanie pojęcia Sztuki, fundującego jej tożsamość jako suwerennej dziedziny badawczej. Szła wraz z tym demistyfikacja konstytuujących ją dyskursów (o pięknie, autonomii Sztuki, geniuszu artystycznym etc.). Analiza dyskursu historii sztuki miała odsłonić jej przesłanki światopoglądowe, założenia i schematy myślowe.

Czy wystąpienie grupy młodych poznańskich historyków sztuki było obliczone na podobny rozgłos i czy mogło liczyć na porównywalne reperkusje? Nie było przecież ograniczone do polemiki z referatem Zofii Ostrowskiej-Kębłowskiej (jak można by sądzić po opublikowanym zapisie). Ostrze krytyki skierowano także przeciw instytucjom polskiego życia naukowego, głównie

${ }^{1}$ M. Bryl, Suwerenność dyscypliny. Polemiczna historia historii sztuki od 1970 roku, Poznań 2008, s. 173 nn. 
przeciwko Stowarzyszeniu Historyków Sztuki, merytorycznej organizacji sesji, skostnieniu i pustej obrzędowości życia naukowego etc. Czy poznańskie wystąpienie stało się, czy mogło się stać porównywalnym succes de scandale, jaką była kolońska „sekcja Warnkego”?

Trzeba wspomnieć, że uczestnicy krytycznej manifestacji na warszawskiej konferencji nie brali udziału ani w tej, ani w żadnej z poprzednich sesji SHS (wyjąwszy wystąpienie Andrzeja Turowskiego, który w roku 1969 na sesji „Sztuka XX wieku” mówił o Strzemińskim²). To dawało im krytyczny rozmach i niezależność, ale $z$ drugiej strony mogli być odbierani jako „obcy", $z$ całym niechętnym bagażem tego słowa. Ich zbiorowe wystąpienie było nieprzewidzianym oficjalnym programem wejściem na środowiskową scenę. Ale na pewno zaprogramowanym. Poznaniacy byli do tego publicznego coming outu świetnie przygotowani. Rok wcześniej, w listopadzie 1973, w zmuzealizowanym pałacu rogalińskim pod Poznaniem miało miejsce bezprecedensowe spotkanie dyskusyjne poznańskich historyków sztuki z Martinem Warnke, poświęcone publikacji Das Kunstwerk zwischen Wissenschaft und Weltanschauung 3 . Polscy historycy sztuki, dokonując analizy materiałów „sekcji Warnkego”, podzielali ich polemiczne podejście do tradycyjnej historii sztuki, opartej na stylistyczno-ikonograficznym paradygmacie. Z oczywistych przyczyn w dyskusji polsko-niemieckiej nastąpiło istotne przesunięcie akcentów $z$ rozliczenia $z$ nazizmem i uwikłania historii sztuki w system kapitalistyczny na zagadnienia czysto metodologiczne, co pozwoliło na dookreślenie ówczesnej polemicznej samoświadomości historii sztuki. Materiały tego spotkania zostały opublikowane, aczkolwiek - jak to w ówczesnej Polsce $-z$ paroletnim poślizgiem $(1976)^{4}$. Dzięki temu jednak spotkanie rogalińskie, zamknięte i niszowe, przez długie lata pozostawało punktem odniesienia wielu debat, interpretowane, rozważane, analizowane, m.in. przez Piotra Piotrowskiego i Mariusza Bryla ${ }^{5}$. W tym miejscu musi być przypomniane jako konieczny element rekonstrukcji sytuacji zaistniałej na konferencji SHS „Myśl o sztuce”. Było bowiem tej sytuacji zapleczem. Polemiści byli świetnie przygotowani, natomiast większość publiczności, do której się zwracali - nie

2 Poprzednie, od roku 1970, sesje SHS były poświęcone tematom: 1970 - „Funkcja dzieła sztuki”; 1971 - „Sztuka 2. połowy XIX wieku”; 1972 - „Sztuka około 1600 roku”; 1973 - „Renesans” (materiały połączone z konferencją PAN w Krakowie); 1974 - „Myśl o sztuce".

${ }^{3}$ Das Kunstwerk zwischen Wissenschaft und Weltanschauung, red. M. Warnke, Gütersloh 1970.

${ }^{4}$ Interpretacja dzieła sztuki. Studia i dyskusje, red. J. Kębłowski, Warszawa-Poznań 1976.

${ }^{5}$ Bryl, Suwerenność dyscypliny, rozdz. III, szczególnie s. 196-201. 
była przygotowana wcale. Stąd efekt szoku i wrażenie nie bardzo zrozumiałej prowokacji, jakich wielu „zwykłych” historyków sztuki doznało w związku $z$ tym wydarzeniem.

Wracając do osobistej perspektywy i pamięci - spotkanie rogalińskie było mi znane, choćby $z$ relacji profesora Białostockiego (jedynego zaproszonego polskiego uczestnika spoza Poznania). Z racji różnych resentymentów niemiecka Ideologiekritik była dla mnie nie do przyjęcia. A jednak, może właśnie za sprawą metodologicznego „oczyszczenia”, jakie przeszła w zderzeniu z polskim kontekstem, pierwsze burzliwe spotkanie $z$ „poznańską historią sztuki" okazało się dla mnie doświadczeniem emancypacyjnym. Bodaj po raz pierwszy w życiu zawodowym doznałam wartości (a może i uroków) buntu i sprzeciwu. Może nawet pokusy ojcobójstwa. Starannie uporządkowana domena, którą winniśmy sobie czynić poddaną, w jaką wprowadzały mnie studia, uległa zaburzeniu i odtąd już nic nie było „na pewno". Historia sztuki objawiła mi się jako nieuładzona, nieprzewidywalna i całkowicie niepodległa kraina wolności. Wolności wyboru dróg do jej rozumienia, badania, także odczuwania. Nie chodziło o zamianę ikonologii na strukturalizm, porzucenie Ernsta Gombricha dla Johna Bergera czy zaniechanie naukowej akrybii na rzecz zideologizowanej publicystycznej pasji. Istotą była sama świadomość możliwości i wolności wyboru. Paradoks może w tym, że „sekcja Warnkego" była ideologicznie wysoce doktrynalna, ale jej duch rewolty niósł ze sobą ducha wolności. Zdaję sobie sprawę, że prawie półwieczny dystans może pamięć mącić, a przede wszystkim sprzyja myśleniu życzeniowemu, kompensacyjnemu, wszelkim mitologizacjom. Lecz w skażonym antropologicznym myśleniem gronie historyków sztuki nie muszę przekonywać o wartości mitologizacji. Tak więc sesja SHS „Myśl o sztuce”, na której zaprezentowałam jedyną w moim dorobku pracę czysto archiwalną, niespodziewanie stała się okolicznością wyzwalającą i pobudzającą do ciągłego krytycznego myślenia, które chroni przed duchowym zniewoleniem. Wnosząc błogosławiony zamęt, wszczepiła mi trwale przekonanie, że mając do czynienia ze sztuką, nigdy nie można się czuć pewnie i bezpiecznie.

\section{BIBLIOGRAFIA}

Bryl M., Suwerenność dyscypliny. Polemiczna historia hisrorii sztuki od 1970 roku, Poznań 2008

Interpretacja dzieła sztuki. Studia i dyskusje, red. J. Białostocki, Warszawa-Poznań 1976

Das Kunstwerk zwischen Wissenschaft und Weltanschauung, red. M. Warnke, Gütersloh 1970 
Maria Poprzęcka

University of Warsaw

\section{ENTER THE DRAGON}

\section{Summary}

The paper is a reminiscence of my first meeting with the colleagues from the Institute of Art History of Adam Mickiewicz University, which took place at an annual conference of the Association of Art Historians in 1974, titled "Reflection on Art." Choosing an unusual title, I wanted to convey the impetus with which a group of young art historians from Poznań entered the decent and somewhat stagnant stage of Polish art history. The critique they presented was directed against Polish academic institutions, the problematic of the conference, the empty rituals of academic life, etc. Even though I did not accept all their objections, the heated debate suddenly turned out for me to be a liberating factor, stimulating continuous critical thinking which is an antidote for spiritual and intellectual captivity.

Keywords:

history of art history, conference, Poznań, Association of Art Historians, institutional critique 